\title{
Multikulturele onderwys vir Suid-Afrika: utopiese ideaal of logiese realiteit?
}

\author{
J. le Roux en T. Möller \\ Dept. Psigo- en Sosiopedagogiek \\ Universiteit van Pretoria \\ PRETORIA
}

\begin{abstract}
Multicultural education for South Africa: utopian ideal or logical reality?

In a new South African dispensation the reconstruction of the global education system necessitates fundamental change to existing educational policies and practices. An educational approach which enjoys increasing attention and consideration today, is multicultural education. South Africa as a multiculiural society needs an educational system that recognises and accommodates the value of ethnic and cultural diversity. Meaningful education takes sociocultural realities into consideration in preparing the youth for a multicultural society of tomorrow. Multicultural education therefore seems to be a logical reality in empowering all children towards adequate and constructive adulthood.
\end{abstract}

\section{Inleiding}

Reeds in 1991 het Sonn (1991:1) verklaar dat onderwys in die brandpunt van die skep van 'n nuwe Suid-Afrika staan, terwyl Maree (1989:17) na onderwys as 'n spanningsveld verwys waarin politieke, sosiale en ekonomiese probleme neerslag vind. Sedert 1990 het regeringsverandering derhalwe ingrypende implikasies vir die onderwys tot gevolg gehad. 1992 was vir die onderwys in die RSA 'n radikale waterskeidingsjaar met ingrypende veranderinge ook ten opsigte van die implementering van multikulturele onderwys (MO) (Van Wyk, 1992:13). Hierdie veranderinge geld onder andere ten opsigte van die volgende aspekte:

- Die afskaffing van onderwysfinansiering

- Die verandering van skole se status

- Die uitfasering van onderwysposte

- Die vermindering van onderwyspersoneel

- Die sluiting en amalgamasie van skole en onderwyskolleges

- Die besinning oor ' $n$ andersoortige onderwyskurrikulummodel

- Die implementering van multikulturele onderwys

Sedert 1993 is eertydse onderwysmodelle deur privaatskole, staatsondersteunde en staatsgefinansierde skole vervang - 'n stap wat tradisioneel-blanke skole vir 
alle bevolkingsgroepe oopgestel het. Suid-Afrika het dus vanaf 'n monokulturele na 'n multikulturele onderwysbeleid beweeg, waar geen diskriminasie op grond van rasse- of kultuurverskille langer regverdigbaar of toelaatbaar was nie (Jordaan, 1995:3).

\section{Prinsipiële begronding}

Omdat onderwys nie los staan van ander gemeenskapsaktiwiteite nie, word dit dan ook universeel blootgestel aan politieke, ekonomiese, ideologiese en filosofiese strominge. Waar Suid-Afrika tans in 'n fase van transformasie staan, word wat die onderwys betref, sulke strominge daadwerklik beleef. Terwyl daar aan die een kant beskuldig word dat die onderwys in diens gestaan het van 'n spesifieke ideologie, word hard probeer om die onderwys aan te wend vir die bevordering van 'n ander ideologie. In die lig van bogenoemde stelling is dit dus die opvoedkundige se taak om te besin oor die verskynsel van multikulturele onderwys in die lig van pedagogies verantwoorde onderwys - nie net om duidelike riglyne te stel in die praktykwording daarvan nie maar ook om die praktyk te evalueer

Onderliggend aan enige gefundeerde onderwyspraktyk staan die moreel etiese beginsel van geregtigheid en menswaardigheid, nie net as 'n rasionele moment nie maar ook as 'n besondere antropologiese fenomeen wat in en deur kultuur tot vergestalting kom

Die kompleksiteit van die Suid-Afrikaanse situasie, soos veral sigbaar word in multi-etnisiteit, verg besinnende denke ten aansien van 'n verbetering van die onderwyspraktyk. 'n Moontlike bydrae tot onderwyspraktykverbetering is geleë in multikulturele onderwys mits dit rekening hou met die reeds gestelde moreel etiese beginsel van geregtigheid en normatiewe waardes voortspruitend daaruit. Die beginsel van geregtigheid is ' $\mathrm{n}$ eg menslike fenomeen wat kultuurgebonde is; daarom is dit wenslik om die begrip kultuur verder te omskryf.

\section{Die begrip kultuur}

Die veeldimensionaliteit van dié konsep bring mee dat daar 'n opvallende gebrek aan konsensus onder navorsers bestaan om kultuur eenduidig te definieer. Voorts word dié konsep vanuit talle perspektiewe verskillend belig. In dié verband verklaar Camilleri (1986:8) dat daar tussen 1871 en 1950 meer as 160 definisies van kultuur wêreldwyd in gebruik was.

Garbers (1988:2) verdeel bestaande definisies aangaande kultuur in vier kategorieë:

- Die definisies wat fokus op dit wat ideaal of voortreflik is. 
- Die definisies wat konsentreer op vasgelegde, tasbare vergestaltings en artifakte.

- Die definisies wat die gewone mens se daaglikse aktiwiteite verwoord.

- Die definisies wat kultuur as 'n dinamiese strategie ter aanpassing by die omgewing beskryf.

Vir die doeleindes van die onderhawige artikel kan kultuur soos volg gedefinieer word: Die universele, onderskeidende karaktertrekke, produkte, waardes, tradisionele gebruike, simbole en aangeleerde aspekte van 'n bepaalde menslike samelewing. Materiële kultuur sluit objekte, tegnologie en kunste in, terwyl niemateriële kultuur verwys na taal en ander simbole, kennis, vaardighede, waardes, geloof en gebruike.

\section{Die begrip multikulturele onderwys}

Sleeter en Grant (1987:421) het, nadat hulle ongeveer 200 tydskrifartikels en 68 boeke omtrent multikulturele onderwys bestudeer het, tot die slotsom gekom dat daar bykans net soveel definisies as navorsers op die terrein van multikulturele onderwys bestaan! Die rede hiervoor is die uiteenlopende aard van onderwysbenaderings ten opsigte van kulturele groepe, asook betekenisse wat aan aspekte soos opvoedingsbeginsels, menseregte, sosialiseringsdoelwitte en onderwys toegedig word.

Claassen (1989:6) beklemtoon dat die blote teenwoordigheid van 'n verskeidenheid kulturele of etniese leergroepe in 'n enkele leersituasie nie noodwendig op multikulturele onderwys dui nie. Derhalwe kan onderwys aan leerlinge van verskillende kultuurgroepe nie sonder meer aan multikulturele onderwys gelykgestel word nie. "Multikultureel" dui op 'n veelheid van kulture wat in die leerstof hetrek word en nie op 'n veelheid van kultuurgroepe in die skool nie.

Multikulturele onderwys as onderwysbenadering wil alle leerlinge in 'n multikulturele gemeenskap onderrig. Hierdie tipe onderwys verteenwoordig ' $n$ omvattende onderwysprogram wat die optimale kognitiewe, affektiewe en sosiale ontwikkeling van leerlinge ten doel stel. Eerstens wil dit leerlinge se kennis aangaande eie kultuurgebruike uitbrei, maar tweedens ook kennis aangaande die gebruike, gewoontes en eienskappe van ander kulture in 'n multikulturele gemeenskap uitbrei. Wedersydse respek, aanvaarding en houdingsveranderinge moet intree, sodat vooroordele ten opsigte van ras, geslag en stereoripering sal verdwyn. Multikulturele onderwys wil leerlinge voorberei vir die werklikhede van 'n multikulturele samelewing, ten einde as volwassenes 'n volwaardige deelgenootskap op ekonomiese, politieke en sosiale terreine te verwerklik (Goodey, 1989:132-133); derhalwe wil multikulturele onderwys as onderwysbenadering die kulturele pluralisme in die totale onderwysstelsel verreken. 


\section{Eienskappe van multikulturele onderwys}

Vervolgens word enkele eienskappe van multikulturele onderwys kortliks gekategoriseer en gesistematiseer (vgl. Goode $y, 1989$; Claassen, 1989; Jordaan, 1995:43-47; Lemmer \& Squelch, 1993:4-5 en Nieto, 1992:208:219):

- Multikulturele onderwys erken die bestaansrealiteit van verskillende etniese, kulturele, taal-, godsdiens- en ander groepe, asook die noodsaaklikheid van die behoud van sodanige groeperinge. Multikulturalisme word verklaar as 'n samelewingstipering, waarin die regte van sowel meerderhede as minderhede erken en gerespekteer word.

- Multikulturele onderwys kweek wedersydse begrip en aanvaarding tussen verskillende kultuurgroepe binne 'n gemeenskaplike geografiese bestel. Aangesien kennis van en waardering vir die eie kultuur belangrik is vir die begrip en aanvaarding van ander kulture, sal wedersydse begrip tussen verskillende kultuurgroepe deur middel van 'n kultuur-diverse onderwysprogram verseker word.

- Moderne kommunikasietegnologie maak multikulturele onderwys as onderwys-strategie in alle mono- en multikulturele samelewings noodsaaklik. Moderne kommunikasietegnologie binne 'n eietydse tegnotroniese bestel het die moontlikheid van daaglikse interkulturele kontak 'n realistiese lewenswyse gemaak - binne sowel multikulturele as monokulturele samelewings. Deur middel van multikulturele onderwys word kinders toegerus om toereikend binne inter- en multikulturele konteks te sosialiseer.

- Multikulturele onderwys is ingestel op die daarstelling van gelyke en gelykwaardige onderwysgeleenthede, ongeag kulturele diversiteit. Binne 'n multikulturele samelewing soos Suid-Afrika, waarin kultuurgroepe as gevolg van kultuurvervreemding en sosio-politiese faktore bepaalde onderwysagterstande vertoon, poog multikulturele onderwys om aan alle leerlinge, met inagneming van kulturele diversiteit, gelyke onderwysgeleenthede te bied.

- Multikulturele onderwys impliseer 'n herstrukturering van die totale skoolomgewing, ten einde 'n multikulturele samelewing te reflekteer. Multikulturele onderwys poog om die multikulturele aard van die eietydse samelewing as uitgangspunt te neem by kurrikuleringsaktiwiteite.

- Binne elke skoolvak behoort 'n multikulturele visie gehandhaaf te word. Multikulturele onderwys mag nie as 'n bepaalde dissipline, toevoeging of onderafdeling van die formele onderwys beskou word nie. Voorts is dit nie 'n skoolvak nie, maar in wese onderwys wat multikultureel van aard is. Derhalwe behoort in elke skoolvak ' $n$ multikulturele visie gehandhaaf te word. 
- Multikulturele onderwys verteenwoordig nie 'n enkelvoudige onderwysmodus of kursus nie, maar 'n veelvoudigheid van programme en praktyke ooreenkomstig die behoeftes van die leerlinge.

- Multikulturele onderwys impliseer effektiewe onderwys wat herstrukturering van die totale onderwysekologiese konteks veronderstel.

- Multikulturele onderwys is nie-rassistiese onderwys. Nie-rassistiese of niediskriminerende onderwys impliseer dat geen leerling ten opsigte van enige onderwysaktiwiteit bevoordeel of benadeel sal word nie. Voorts beteken dit dat rassisme doelgerig teëgewerk sal word deur interkulturele sosiale vaardighede by leerlinge te ontwikkel.

- Multikulturele onderwys is basiese onderwys. Multikulturele geletterdheid word as 'n basiese komponent naas reken-, skryf- en leesvaardighede, as primêre opgawe van die skool erken

- Multikulturele onderwys is deurlopend. Multikulturele onderwys impliseer 'n totaal-omvattende onderwysfilosofie of perspektief en nie bloot ' $n$ addisionele vak of aspek binne die skoolprogram nie. Dit is derhalwe 'n kontinue proses en nie ' $n$ ad hoc-reëling nie.

Multikulturele onderwys is onderwys vir sosiale gelykberegtiging. Onderwys behoort samelewingsrealiteite te reflekteer, en omgekeerd: "Multicultural education invites students and teachers to put their learning into actions for social justice" (Lemmer \& Squelch, 1993:4).

- Multikulturele onderwys is kritiese ondenwys. Kennis is nooit neutraal of apolities nie, ofskoon dit dikwels sodanig deur onderwysers gehanteer word. Die geskiedenis bestaan uit kontroversiële geskille en ideologiese verskille en gesprekvoering. Die skool het dan ook die opgawe om leerlinge tot besluitnemingsvaardighede, kritiese denke en sosiale kennis en insigte op te voed. Dit is juis die teenoorgestelde as die verknegting of domesticating education wat vry algemeen in skole as uitgangspunt geld.

\section{Mites aangaande multikulturele onderwys}

As gevolg van 'n gebrek aan eenduidige omskrywing, leen dié konsep sigself tot uiteenlopende interpretasiemoontlikhede. Vervolgens word enkele van sodanige mites rondom multikulturele onderwys kortliks aangedui (vgl. Goodey, 1989:114118):

- Multikulturele onderwys beteken in wese "onderwys in 'n multikulturele samelewing". 'n Foutiewe aanname is naamlik dat multikulturele onderwys bloot onderwys in 'n multikulturele samelewing veronderstel. Voorts word dit 
Multikulturele onderwys vir Suid-Afrika: utopiese ideaal of logiese realiteit?

verkeerdelik veronderstel dat multikulturele onderwys bedryf word in enige onderwyssituasie waar leerlinge van verskillende kultuurgroepe binne een skool of klassituasie teenwoordig is. Multikulturele onderwys daarenteen, is 'n onderwysbenadering met unieke eienskappe, doelstellings en teorieë. Dit is 'n onderwysbenadering naas ander benaderings soos interkulturele onderwys, multi-etniese onderwys, etnosentriese onderwys of tweetalige onderwys.

- Multikulturele onderwys kan slegs in multikulturele skole bedryf word. 'n Verdere wanpersepsie is dat multikulturele onderwys slegs moontlik is in skole met 'n multikulturele karakter of samestelling. Navorsers beklemtoon egter dat multikulturele onderwys ook binne monokulturele skole moontlik en maklik implementeerbaar is. Sodoende kan wedersydse agting en waardering by kinders in 'n monokulturele skool aangeleer word vir die realiteit van 'n multikulturele samelewing.

- Multikulturele ondenwys impliseer noodwendig geintegreerde skole. Talle persone en organisasies is verkeerdelik van mening dat multikulturele onderwys met gemengde onderwys gelykgestel kan word. Sodanig sal die verbintenisse met die eie etniese en kultuurgroep kwansuis verbreek word. Binne multikulturele onderwys vorm die behoud van die eie en die erkenning van kultuurdiversiteit juis die hoekstene van dié benadering, asook van kulturele pluralisme.

- Multikulturele onderwys is ' $n$ voortsetting van aparte onderwys. Die mite bestaan voorts dat multikulturele onderwys groepverskille (diversiteit) in die beklemtoning van etnisiteit kan verabsoluteer. Teoreties beskou, propageer multikulturele onderwys egter 'n balans tussen gemeenskaplikheid en diversiteit: dus tussen individuele en groepsbelange.

- Multikulturele onderwys dui op kultuurgroepe in 'n onderwyssituasie en nie op die totale onderwysprogram nie. Die mite bestaan dat die blote teenwoordigheid van groepe leerlinge afkomstig uit 'n kultuurverskeidenheid noodwendig op die aktualisering van multikulturele onderwys dui. "Multikultureel" dui veel eerder op 'n totale gees of "etos" in 'n bepaalde onderwysinstelling waar moreel etiese beginsels gerespekteer word.

\section{Evaluering van multikulturele onderwys}

'n Evaluering van multikulturele onderwys bring talle punte van kritiek na vore, soos duidelik blyk uit 'n literatuurondersoek ten opsigte van dié onderwysbenadering (vgl. Jordaan, 1995:47-49; Goodey, 1989:118-119):

- Kritici beskou multikulturele onderwys geredelik as bloot 'n versluierde vorm van gemengde of geintegreerde onderwys; of andersyds as 'n voortsetting van 
apartheidsonderwys in verbloemde vorm. Die essensie van multikulturele onderwys is juis om gemeenskaplikheid en diversiteit binne 'n nuwe benadering te akkommodeer.

- Uit sekere oorde word multikulturele onderwys gedegradeer as bloot die teenwoordigheid van verskillende kultuurgroepe in 'n gemeenskaplike Westers-georiënteerde onderwyssituasie. Multikulturele onderwys is juis op die behoud en uitbouing van minderheidskulture ingestel

- Talle navorsers is van mening dat multikulturele onderwys 'n idealistiese teorie verteenwoordig wat nie in die onderwyspraktyk haalbaar is nie. Onderwys sonder ideale is stagnant. Multikulturele onderwys wil juis die kind opvoed tot die beoefening van persoonlike verantwoordelikheid en solidariteit in 'n multikulturele gemeenskap.

- Kritici is van mening dat multikulturele onderwys leerlinge belemmer in die aanleer en bemeestering van basiese akademiese vaardighede. Dié kritiek word weerlê deur die doelstellings van multikulturele onderwys, waar basiese vaardighede as voorwaarde vir toereikende sosialisering binne 'n kultureeldiverse samelewing beklemtoon word.

- Uit sommige oorde word nie-rassistiese onderwysinhoude en -metodes binne 'n multikulturele onderwysbenadering as kultuurvreemd vir leerlinge beskou. Dié argument word weerlê deur voorstanders van multikulturele onderwys, wat beklemtoon dat gemeenskaplike aspekte binne 'n nuwe kurrikulum ingebou moet word.

- Teenstanders van multikulturele onderwys se beswaar is voorts dat leerlinge in 'n bepaalde kultuurmilieu gebore word en dat hul eers dié kultuuridentiteit moet bestendig, alvorens kennis van ander kulture bygebring moet word. So ' $n$ benadering staan lynreg in teenstelling tot die beskouing dat multikulturele onderwys juis aan leerlinge die geleentheid bied om hul eie kultuur beter te begryp en uit te leef.

- Sommige navorsers is van mening dat multikulturele onderwys se onderliggende aannames idealisties van aard is en nie grondliggende aspekte soos rassisme en kulturele vooroordele ondervang nie. Geregtigheid en agting vir menswaardigheid is besondere beginsels van multikulturele onderwys Vooroordele word juis teengewerk.

- Uit sommige oorde word gepropageer dat die doelstellings en doelwitte van multikulturele onderwys vaag en ongedefinieerd is. Die hoofdoelstelling van multikulturele onderwys is effektiewe opvoeding. Die kurrikulum moet dus 
Multikulturele onderwys vir Suid-Afrika: utopiese ideaal of logiese realiteit?

die geestelike en materiële behoeftes van 'n multikulturele gemeenskap akkommodeer.

- In Suid-Afrika word daar uit bepaalde oorde gepropageer dat totale skeiding tussen groepe die mees aangewese wyse is om vreedsame naasbestaan te verseker. Hierdie houding spruit uit 'n vorige politieke bedeling wat ook in onderwysvoorsiening beslag gekry het. Die geskiedenis toon egter dat skeiding geredelik tot konflik aanleiding gee. Multikulturele onderwys wil dié onnatuurlike skeiding tussen groepe ophef. Sodoende word aan elke kultuurgroep die geleentheid gebied om sy eie kultuur te handhaaf, maar om terselfdertyd ander se kulture te begryp en 'n positiewe houding daarteenoor te ontwikkel.

\section{Multikulturele onderwys: 'n logiese realiteit vir die RSA}

... historically, education's prime task in all societies has been to conserve and protect an inherited culture and transmit it intact to each generation (Coombs, 1985:244).

Die rol van onderwys as kultuuroordrag moet deurlopend aan die beginsel van kultuurkontinuilteit gemeet word. Indien kultuur egter onveranderd van een generasie na 'n volgende oorgedra word, kan die beginsel van kultuurdifferensiasie verabsoluteer word. Die oordra van vernuwende denke, nuwe tegnologies-wetenskaplike kennis en uitvindings dui op die verband tussen kultuurskepping en -oordrag deur opvoedende onderwys. Andersyds het kultuurvernuwing en -vooruitgang 'n bepaalde effek op die onderwys. Die onderwys is en bly derhalwe een van die mees betekenisvolle instrumente in die proses van kultuurskepping, kultuurontwikkeling en kultuurdisseminering (Goodey, 1989:25-26).

Binne 'n multikulturele samelewing soos Suid-Afrika moet kultuuroordrag as onderskeibare taak van die skool, die multikulturele aard van die samelewing reflekteer. Derhalwe herformuleer die plurale karakter van die eietydse SuidAfrikaanse samelewing opnuut die vraag na die verband tussen onderwys en kultuur. Die toenemende bewuswording van kulturaliteit plaas opnuut die fokus op multikulturele onderwys as strategie vir kurrikulering, onderwysersopleiding en die bestaande onderwyspraktyk.

Dit is noodsaaklik dat onderwys heersende meningsvorming, maatskaplike behoeftes en ekonomies-politiese veranderinge sal verdiskonteer. Slegs indien onderwysvoorsiening dit ten doel stel, kan die lewensgehalte van alle SuidAfrikaners verbeter word en kan die skool as samelewingsinstituut die grootwordende generasie op metodiese wyse voorsien van vaardighede en kennis, ten einde later as volwassenes 'n toereikende deelgenootskap aan en 'n 
konstruktiewe bydrae tot 'n multikulturele samelewing te lewer. Indien die primêre taak van die skool as formeel-gestruktureerde en geselekteerde kultuuroordrag beskou word, behoort formele onderwys die eie aard en karakter van 'n samelewing te reflekteer. Binne 'n kaleidoskopiese kosmos in die RSA met 'n ryke kultuurdiversiteit, blyk multikulturele onderwys derhalwe 'n logiese realiteit te wees - 'n realiteit wat nie net aanvaarbaar is vir diegene wat 'n Christelike lewensbeskouing aanhang nie, maar vir alle kulture wat geregtigheid en agting vir menswaardigheid hoog aanslaan.

\section{Verwysings}

CAMILLERI, C. 1986. Cultural anthropology and education. New York : Kogan Page \& UNESCO

CLAASSEN, J.C. 1989. Multikulturele onderwys: 'n studie in die Vergelykende Opvoedkunde. Bloemfontein : Universiteit van die Oranje-Vrystaat. (D.Ed.-proefskrif.)

COOMBS, P.H. 1985. The world crisis in education: the view from the eighties. New York : Oxford University Press.

GARBERS, J.G. 1988. Kultuurbewaring binne 'n dinamiese multikulturele Suid-Afrika Hoofrede gelewer tydens die Suid-Afrikaanse Konferensie oor Kultuurbewaring op 6 Junie 1988 te Kaapstad.

GOODEY, J.S. 1989. Multikulturele onderwys: ideaal en werklikheid. Pretoria : Universiteit van Suid-Afrika. (D.Ed.-proefskrif.)

JORDAAN, E. 1995. Die rol van liggaamlike opvoeding en sport in die oordra van waardes aan die primêreskoolkind in 'n multikulturele samelewing. Bloemfontein : Universiteit van die Oranje-Vrystaat. (D.Ed -proefskrif.)

LEMMER, E. \& SQUELCH, J. 1993. Multicultural education. A teacher's manual. Pretoria : Sigma Press.

MAREE, P.J. 1989. Die onderwyser as konflikfiguur. Fasette 112-119, Junie.

NIETO, S. 1992. Affirming diversity. The sociopolitical context of multicultural education. New York : Longman.

SLEETER, C.E. \& GRANT, C.A. 1987. An analysis of multicultural education in the United States. Harvard Educational Review, 57(4):421-444

SONN, F. 1991. Die nuwe onderwys uit my perspektief. Referaat gelewer by die Nasionale Onderwyssimposium te Bloemfontein op 19 April 1991

VAN WYK, A.L. 1992. Onderwysvraagstukke in 'n toekomstige RSA. Die Unie, 89(1) 1319. 